\title{
(Komunikasi Singkat) Studi Pembenihan Kerapu Macan (Epinephelus fuscoguttatus) Skala Rumah Tangga di Desa Penyabangan, Kecamatan Gerokgak, Kabupaten Buleleng, Provinsi Bali
}

\section{(Short Communication) Study of the Hatchery of Tiger Grouper (Epinephelus fuscoguttatus) Household Scale in Penyabangan Village, Gerokgak District, Buleleng Regency, Bali Province}

\author{
I Komang Yudha Wirawan ${ }^{1}$, Liga Insani ${ }^{1}$, Muhammad Sulaiman Dadiono ${ }^{2 *}$ \\ ${ }^{1}$ Politeknik Keautan dan Perikanan Jembrana, Pengambengan, Negara, Kabupaten Jembrana, Bali \\ 2 Program Studi Budidaya Perairan, Fakultas Perikanan dan Ilmu Kelautan, Universitas Jenderal \\ Soedirman, J1. Dr Soeparno, Komplek GOR Soesilo Soedarman, Karangwangkal, Karang Bawang, \\ Grendeng, Kec. Purwokerto Utara, Kabupaten Banyumas, Jawa Tengah \\ *Email: sdadiono@unsoed.ac.id
}

Received : 22 February 2020

Accepted : 27 March 2020

Publish : 31 April 2020

\section{Abstrak}

Pembenihan kerapu macan (Epinephelus fuscogutattus) skala rumah tangga merupakan salah satu penyumbang peningkatan produksi benih kerapu nasional. dengan adanya pembenihan kerapu skala rumah tangga permintaan akan benih kerapu bisa terpenuhi serta meningkatkan perekonomian masyarakat. Studi ini bertujuan untuk mengetahui pembenihan kerapu macan skala rumah tangga yang meliputi penyediaan pakan, penetasan telur, pengelolaan kualitas air, pemanenan, Hatching Rate (HR) dan Survival Rate (SR). Metode pengambilan data dengan cara wawancara, observasi dan partisipasi aktif. Hasil observasi terkait pembenihan dimulai dengan penyediaan pakan alami hingga proses pemanenan benih berukuran 2,7-3 cm. Hatching Rate (HR) mencapai $80 \%$ dan Survival Rate (SR) mencapai 20\%. Benih yang dihasilkan sebanyak 120.000 ekor/siklus. Hasil panen benih sebanyak 24.000 ekor/siklus.

Keyword : Pembenihan, Kerapu Macan, Epinephelus fuscogutattus, Skala Rumah Tangga.

\section{Abstract}

Hatchery of tiger grouper (Epinephelus fuscogutattus) household scale is one of the contributors to the increase in national grouper seed production. with the hatchery of householdscale grouper, the demand for grouper seed can be fulfilled as well as improving the community's economy. This study aims to determine the hatchery of household-scale tiger grouper which includes the provision of feed, hatching eggs, water quality management, harvesting, Hatching Rate (HR) and Survival Rate (SR). Data collection methods by interview, observation and active participation. Observation results related to seeding began with the provision of natural food to harvest the seeds measuring 2.7-3 cm. Hatching Rate (HR) reaches $80 \%$ and Survival Rate (SR) reaches $20 \%$. The seeds produced were 120,000 per cycle. Seed yields are 24,000 per cycle.

Keyword : Hatchery, Tiger Grouper, Epinephelus fuscogutattus, Household Scale 


\section{PENDAHULUAN}

Masalah umum budidaya kerapu adalah cara mendapatkan benih unggul yang memiliki pertumbuhan yang cepat, FCR rendah, tahan terhadap perubahan lingkungan, tahan penyakit dan memiliki morfologi yang menarik. Salah satu jenis ikan kerapu yang disukai oleh pembudidaya kerapu di pesisir Bali Utara adalah jenis kerapu macan (Sutarmat dan Hirmawan, 2013). Kerapu macan (Epinephelus fuscogutattus) merupakan komoditas perikanan budidaya yang unggul, memiliki nilai ekonomis tinggi serta menjadi salah satu komoditas ekspor (Lutfiyah dan Budi, 2019).

Sepanjang pesisir pantai Bali Utara terdapat banyak pembudidaya kerapu macan mulai dari skala kecil maupun skala industri (Ismi et al., 2012). Pembenihan kerapu macan (E. fuscogutattus) skala rumah tangga merupakan salah satu penyumbang peningkatan produksi benih kerapu nasional. dengan adanya pembenihan kerapu skala rumah tangga permintaan akan benih kerapu bisa terpenuhi serta meningkatkan perekonomian masyarakat Bali Utara. Tujuan studi ini untuk mengetahui pembenihan kerapu macan skala rumah tangga di Desa Penyabangan, Kecamatan Gerokgak, Kabupaten Buleleng, Provinsi Bali, yang meliputi penyediaan pakan, penetasan telur, pengelolaan kualitas air, pengendalian hama dan penyakit, pemanenan benih, Hatching Rate (HR) dan Survival Rate (SR).

\section{METODE PENELITIAN}

\section{Waktu dan Tempat}

Studi ini dilakukan pada bulan Oktober 2019 di "Apri Hatchery" yang terletak di Desa Penyabangan, Kecamatan Gerokgak, Kabupaten Buleleng, Provinsi Bali.

\section{Metode Pengambilan Data}

Metode pengambilan data studi ini dilakukan partisipasi aktif, wawancara dan observasi langsung di pembenihan kerapu macan yang masih tergolong skala rumah tangga di Desa Penyabangan, Kecamatan Gerokgak, Kabupaten Buleleng, Provinsi Bali. Selama bulan Oktober 2019.

Wawancara lebih ditekankan untuk mengambil data secara langsung kepada narasumber di lokasi. Pemeriksaan sampel udang vaname yang positif terinfeksi virus 
kemudian dihitung dan dianalisa berdasarkan perhitungan matematik untuk mengetahui menilai prevalensi. Nilai prevalensi digunakan untuk mengetahui banyaknya udang yang terinfeksi virus. Prevalensi dapat dihitung menggunakan rumus menurut Cameron (2002).

\section{HASIL DAN PEMBAHASAN}

Pakan alami yang digunakan pada pembenihan ikan kerapu macan adalah Nannochloropsis, Rotifer, Artemia dan rebon. Seluruh pakan

Tabel 1. Pemberian pakan alami pada larva ikan kerapu macan

\begin{tabular}{llll}
\hline Umur (Hari) & Jenis Pakan & Frekuensi & Dosis \\
\hline D0 & - & - & - \\
D1 & Makanan cadangan (kuning & - & - \\
& telur) & & \\
D2 - D14 & Nannochloropsis & 2 kali sehari & $1 \mathrm{jt} \mathrm{sel/ml}$ \\
& Rotifer & 2 kali sehari & $300-500$ \\
& & & individu/larva \\
D15-D30 & Nannochloropsis & 2 kali sehari & 1 jt sel/ml \\
& Rotifer & 2 kali sehari & $300-500$ \\
& Artemia & 2 kali sehari & individu/larva \\
& Pakan buatan & $3-4$ kali sehari & $30-40$ individu/larva \\
& & & Ad-libitum \\
D31-D40 & Rotifer & 2 kali sehari & $300-500$ \\
& Artemia & 2 kali sehari & individu/larva \\
& Pakan buatan & $3-4$ kali sehari & $60-75$ individu/larva \\
& Rebon & 1 kali sehari & Ad-libitum \\
& & & Ad-libitum \\
D41 - Panen & Artemia & 2 kali sehari & $60-75$ individu/larva \\
& Pakan buatan & $3-4$ kali sehari & Ad-libitum \\
& Rebon & 1 kali sehari & Ad-libitum \\
\hline
\end{tabular}

Tabel 2. Kandungan gizi pakan komersil merk Otohime

\begin{tabular}{llllllll}
\hline & & \multicolumn{5}{c}{ Kandungan Gizi } \\
\cline { 3 - 7 } Tipe & \multirow{2}{*}{ Ukuran } & $\begin{array}{l}\text { Protein } \\
\text { \% Min }\end{array}$ & $\begin{array}{l}\text { Lemak } \\
\text { \% Min }\end{array}$ & $\begin{array}{l}\text { Serat } \\
\text { \% Min }\end{array}$ & $\begin{array}{l}\text { Abu \% } \\
\text { Min }\end{array}$ & $\begin{array}{l}\text { Kalsium } \\
\text { \% Min }\end{array}$ & Kemasan \\
\hline B1 & $360 \mu \mathrm{m}$ & 50 & 10 & 3 & 16 & 2,3 & $2 \mathrm{~kg} / \mathrm{pak}$ \\
B2 & $360-580 \mu \mathrm{m}$ & 50 & 10 & 3 & 16 & 2,3 & $2 \mathrm{~kg} / \mathrm{pak}$ \\
$\mathrm{C} 1$ & $580-910 \mu \mathrm{m}$ & 50 & 10 & 3 & 16 & 2,3 & $2 \mathrm{~kg} / \mathrm{pak}$ \\
$\mathrm{S} 1$ & $1,0 \mathrm{~mm}$ & 50 & 10 & 3 & 16 & 2,3 & $2 \mathrm{~kg} / \mathrm{pak}$ \\
\hline
\end{tabular}

tersebut disediakan sesuai dengan umur dan jumlah larva ikan kerapu macan (Tabel 1). Selanjutnya, pakan buatan yang diaplikasikan pada larva menggunakan jenis pakan komersil dengan merk Otohime dengan 4 tipe pakan. Yaitu Otohime B1, Otohime B2, Otohime C1 dan Otohime S1. Pakan buatan diberikan untuk larva ketika memasuki umur 15 hari. Kandungan dari pakan merk Otohime tertera pada (Tabel 2). 
Journal of Aquaculture Science

DOI: https://doi.org/10.31093/joas.v5i1.82

\section{Penetasan Telur}

Telur kerapu macan yang ditebar pada bak penetasan dengan kepadatan 5 butir per liter dengan total jumlah tebar sebanyak 3 kantong yang berisi 150.000 butir. Telur diaklimatisasi selama 15 menit sebelum ditebar ke dalam bak penetasan. Telur kerapu macan menetas setelah 20 - 24 jam setelah pemijahan.

Hal ini tidak jauh berbeda dengan pernyataan Mayunar et al. (1991) secara keseluruhan, waktu inkubasi telur ikan kerapu macan berkisar antara 16 - 22 jam pada temperatur $28-30^{\circ} \mathrm{C}$ dan salinitas $32-34$ ppt.

\section{Pengelolaan Kualitas Air}

Pergantian air dilakukan ketika larva kerapu macan memasuki Tabel 3. Kualitas air pemeliharaan larva ikan kerapu macan
April 2020 vol 5 (1): 1-7

Online pada http://joas.co.id

umur 15 hari (D15). Pergantian air dilakukan setiap satu hari sekali dengan pergantian sebanyak $20 \%-$ $50 \%$ dari volume air di dalam bak pemeliharaan larva.

Selain pergantian air, penyiponan juga dilakukan setiap hari ketika larva memasuki umur 17 hari (D17) hingga panen. Parameter kualitas air yang diukur selama pemeliharaan larva kerapu macan yaitu salinitas, $\mathrm{pH}$, DO dan suhu pada bak pemeliharaan.

Hasil pengukuran tertera pada Tabel 3. Menurut Ismi et al. (2018), kualitas air pada bak pemeliharaan ikan kerapu haruslah terkontrol dengan suhu air antara $29{ }^{\circ} \mathrm{C}$ sampai $30{ }^{\circ} \mathrm{C}$ dengan perbedaan suhu maksimum dan minimum sebesar 1 ${ }^{\circ} \mathrm{C}-1,5{ }^{\circ} \mathrm{C}$.

\begin{tabular}{lllll}
\hline No & Parameter & Nilai & Optimal & Refrensi \\
\hline 1 & Salinitas & $35 \mathrm{ppt}$ & $28-33 \mathrm{ppt}$ & \\
2 & pH & 7,4 & $7,5-8,5$ & Standar Nasional \\
3 & DO & $6,5 \mathrm{ppm}$ & Min. $4 \mathrm{ppm}$ & Indonesia (SNI) \\
4 & Suhu & $29,4{ }^{\circ} \mathrm{C}$ & $28-32^{\circ} \mathrm{C}$ & \\
\hline
\end{tabular}

\section{Pengendalian Hama dan Penyakit}

Pengendalian hama dan penyakit merupakan faktor penentu untuk keberhasilan dalam usaha pembenihan kerapu macan skala rumah tangga di Desa Penyabangan, Kecamatan Gerokgak, Kabupaten 
Journal of Aquaculture Science

DOI: https://doi.org/10.31093/joas.v5i1.82

Buleleng, Provinsi Bali. Upaya yang

dilakukan pada usaha pembenihan kerapu macan skala rumah tangga di Buleleng untuk mencegah timbulnya penyakit dengan pemberian obat elbayou yang dilarutkan pada artemia yang akan diberikan kepada larva.

Dosis pemberian elbayou yaitu sebanyak $10 \mathrm{ppm}$. Sedangkan berdasarkan studi yang dilakukan Widyawan (2006) upaya pencegahan penyakit pada pembenihan kerapu macan skala rumah tangga di Situbondo dilakukan dengan pemberian Elbasin sebanyak 0,25 ppm dan Malacyte Green sebanyak $0,1 \mathrm{ppm}$. Berarti upaya pencegahan penyakit pada usaha pembenihan kerapu macan skala rumah tangga di Buleleng lebih sederhana jika dibandingkan upaya yang dilakukan pada pembenihan kerapu macan skala rumah tangga di Situbondo.

\section{Panen Benih}

Pemanenan benih kerapu
macan dilakukan ketika benih
memiliki panjang antara $2,7-3 \mathrm{~cm}$.
Pada umumnya benih mencapai
ukuran tersebut pada saat benih
memasuki umur $40-45$ hari (D40-
D45). Selain untuk menghitung

April 2020 vol 5 (1): 1-7

Online pada http://joas.co.id

jumlah, panen juga bertujuan untuk menyeleksi ukuran sehingga tidak terjadi kanibalisme. Panen dilakukan dengan cara mengurangi volume air bak hingga mencapai ketinggian 30 $\mathrm{cm}$.

Benih digiring ke sudut bak kemudian diseser secara perlahan dan dipindahkan ke tempat grading untuk menyesuaikan ukuran dan kondisi fisik yang baik. Kondisi fisik yang baik yaitu tidak adanya luka dan cacat fisik. Pernyataan ini sesuai dengan SNI (2011) dimana bentuk tubuh benih normal, lengkap, serta tidak tampak kelainan genetik.

\section{Analisa Produksi}

Analisa produksi yang dimaksud diantaranya yaitu Hatching Rate (HR) dan Survival Rate (SR).

\section{Hatching Rate (HR)}

HR (Hatching Rate) adalah daya tetas telur berdasarkan jumlah telur yang ditebar dengan jumlah telur yang menetas. Penghitungan HR dilakukan dengan pengambilan sampel setelah telur menetas dengan menggunakan beaker glass. Setelah diambil, kemudian dihitung dan dikalkulasikan dengan volume bak penetasan sehingga memperoleh 
Journal of Aquaculture Science

DOI: https://doi.org/10.31093/joas.v5i1.82

hasil $80 \%$ atau sebanyak 120.000 larva yang menetas dari 150.000 butir telur yang ditebar.

\section{Survival Rate (SR)}

SR (Survival Rate) merupakan tingkat kelulus hidupan benih ikan kerapu macan selama pemeliharaan. SR diperoleh setelah pemanenan benih berdasarkan jumlah benih yang diperoleh. SR Pada siklus sebelumnya mencapai $20 \%$, jadi benih yang diperoleh pada siklus sebelumnya yaitu sebanyak 24.000 ekor benih kerapu macan. SR dipengaruhi banyak faktor, termasuk padat tebar yang terlalu tinggi (Faruq et al., 2019).

\section{KESIMPULAN}

Pembenihan ikan kerapu macan skala rumah tangga di "Apri Hatchery" yang terletak di Desa Penyabangan, Kecamatan Gerokgak, Kabupaten Buleleng, Provinsi Bali dimulai dari persiapan bak penetasan, penebaran dan penetasan telur, pemeliharaan larva hingga panen. Teknik pemijahan yang dilakukan di "Apri Hatchery" tergolong pemijahan alami, karena menurut Apri, Indukan kerapu macan menghasilkan telur yang lebih
April 2020 vol 5 (1): 1-7

Online pada http://joas.co.id

berkualitas apabila dilakukan secara alami. Pengendalian penyakit dilakukan dengan pemberian obat elbayou yang dilarutkan pada artemia yang akan diberikan kepada larva dengan dosis pemberian elbayou sebesar 10 ppm. Hasil produksi pada pembenihan kerapu macan skala rumah tangga pada siklus sebelumnya mampu menghasilkan 24.000 ekor benih ikan kerapu macan dengan SR $20 \%$. Dengan harga jual Rp 1.300 per ekor benih ukuran $2,7-3 \mathrm{~cm}$.

\section{Ucapan Terima Kasih}

Terima kasih kami ucapkan kepada bapak Apri selaku pemilik “Apri Hatchery" sebagai usaha pembenihan kerapu macan skala rumah tangga yang dijadikan tempat studi, para taruna dan dosen Politeknik Kelautan dan Perikanan Jembrana yang telah mendukung penelitian dan penulisan artikel ilmiah ini.

\section{DAFTAR PUSTAKA}

Faruq, U., R. Jumadi, M. S. Dadiono. 2019. Pengaruh Frekuensi Pemberian Pakan yang Berbeda Terhadap Pertumbuhan Ikan Bandeng (Chanos chanos). Jurnal Perikanan Pantura, 2(1): 1016.DOI: http://dx.doi.org/10.30587/jp p.v2i1.806. 
Ismi, S., T. Sutarmat, N.A. Giri, M.A. Rimmer, R.M.J. Knuckey, A.C. Berding, K. Sugama. 2012. Nursery management of grouper: a bestpractice manual. ACIAR Monograph No. 150. Australian Centre for International Agricultural Research, Canberra.

Ismi, S., J. H. Hutapea, D. Kusumawati, Y. N. Asih. 2018. Perkembangan Morfologi dan Perilaku Larva Ikan Kerapu Hibrida Cantik pada Produksi Massal. Jurnal Ilmu dan Teknologi Kelautan Tropis. 10(2): 431-440. DOI:http://dx.doi.org/10.29244/jitkt. v10i2.21825.

Lutfiyah, L., D. S. Budi. 2019. Fluctuation of Asymmetry of Hybrid Cantang Grouper (Epinephelus fuscoguttatus $\mathrm{x}$ Epinephelus lanceolatus) Originating from Situbondo and Bali. Journal of Aquaculture Science, 4(1): 21-26. DOI:https://doi.org/10.31093/joas.v4i 1.65 .

Mayunar, S. Diani, B. Slamet. 1991. Fekunditas, derajat pembuahan dan derajat penetasan telur ika kerapu macan, Epinephelus fuscogutattus yag diberi ransum berbeda. Jurnal Peneliti Budidaya Pantai, 7(2): 1-9.

Sutarmat, T. dan Hirmawan T.Y. 2013. Analisis keragaan pertumbuhan benih ikan kerapu hasil hibridisasi kerapu macan (Ephinephelus fuscoguttatus) dengan kerapu kertang (Ephinephelus lanceolatus) dan kerapu batik (Ephinephelus microdon). Jurnal Riset Akuakultur, 8(3): 363-372.

SNI. 2011. Ikan kerapu macan (Epinephelus fuscoguttatus, Foskal) - Bagian 2: Benih kerapu macan. BSN. Jakarta.

Widyawan, MRH. 2006. Teknik Pembenihan Ikan Kerapu Macan (Epinephelus fuscogutattus) Skala Rumah Tangga di Dusun Pecaron Desa Klatakan Kecamatan Kendit Kabupaten Situbondo Propinsi Jawa Timur [PKL]. Surabaya (ID): Universitas Airlangga. 